\title{
Review
}

\section{Judicial Review: Old and New}

\author{
Keith Rosennt
}

Judicial Review in the Contemporary World. By Mauro Cappelletti. Indianapolis: Bobbs-Merrill Company, Inc. 1971. Pp. xw, 117. \$8.50.

Professor Cappelletti, one of Italy's most distinguished procedural law scholars, has completed an important comparative study of the practice of judicial review in many nations, focusing primarily on Western Europe and the United States. ${ }^{1}$ His point of view is highly theoretical; his perspective, broad and provocative. Compressed into 100 pages of text and detailed footnotes is a wealth of information on a variety of legal systems and techniques.

In the first part of his book, Professor Cappelletti deftly traces the development of judicial review from the ancient Athenians to John Marshall. This historical analysis is presented in terms of the classic Hegelian dialectic, complete with thesis, antithesis, and synthesis." The first stage, or thesis, was "natural justice," essentially the "right reason" of Greco-Roman law, generously infused with Christian theology, and epitomized by the Thomistic doctrine that an unjust law is not law at all. ${ }^{3}$ The necessity for positive law's conformance with

$\dagger$ Professor of Law, Ohio State University College of Law.

1. M. CAPpellettr, Judiclal Review in THE Contesirorari WorLd vii-x (1971) [hereinafter cited as CAppellemt]. See also Cappelletti, The Significance of Judicial Review of Legislation in the Contemporary World, in Its Privitug GestIus 147, 155-57 (E. von Caemmerer, S. Mentshikoff \& K. Zwcigert eds. 1969).

For other comparative studies of judicial review see Mix Plater Isstrtur Fun Aus. LANDISCHES OFFENTILICHES REChT UND VOLRERRECIT, Verfassuncscenicimsuakheit IN Der Gecenwart (H. Mosler ed. 1962); E. McW'uinex, Judicial Review (th ed. 1969); J. Othon Sibou, Do Mandado De Seguranca $101-223$ (3d cd. 1969); E. V'escoit, Et. Proceso De Inconstrtucionalidad De La LeY (1967); H. Zaimedo, Veinticinco ANǘs DE Erolu. ción DE LA Justicia Constrrucional 1940-1965 (1968); Geck, Judicial Revieu of Stalutes: A Comparative Survey of Present Institutions and Practices, 51 Consect L.Q. 250 (1960).

2. Cappentetti viii-ix.

3. II Basic Writings of St. Thomas aguinas 784 (A. Pegis ed. 1915). 
"natural law" was asserted by philosopher-jurists during this stage. But there existed no enforcement mechanism, except for an occasional judicial pronouncement or rebellion. ${ }^{4}$ The second stage, or antithesis, was "legal justice," the legal positivism which continues to dominate French and English constitutional practice. This view was embodied in England's Glorious Revolution of 1688 and the French Revolution of 1789 , when the populace rejected any judicial restraint on legislative sovereignty. "Legal justice" was

characterized by the primacy of the written statute and the popular legislature, and the relative powerlessness of both judges and natural law theory to control this primacy. ${ }^{5}$

Finally, in the third stage, "constitutional justice" synthesized the two preceding stages by "positivizing" natural law precepts in written, "rigid" constitutions, and by entrusting the judiciary with the task of determining whether laws violated constitutional provisions." This last stage began in 1803 with Marbury v. Madison, although as Pro. fessor Cappelletti carefully notes:

[M]ore than a century of American history and a strong line of precedents-to say nothing of contemporary writings-stood behind Chief Justice Marshall in 1803 when ... he enunciated "the principle, supposed to be essential to all written constitutions, that a law repugnant to the Constitution is void; and that Courts, as well as other departments, are bound by that instrument." 8

Cappelletti contends that this pattern of articulating "higher law" in a written constitution enforced by the judiciary is a world-wide trend, a development which the author later labels the "judicial review explosion."

4. The most famous English example of such pronouncement appearcd in Cokc's dictum in Bonham's Case in 1610: "that in many cases, the common law will controul acts of parliament, and sometimes adjudge them to be utterly void: for when an act of parliament is against common right and reason, or repugnant, or impossible to be performed, the common law will controul it and adjudge it to be void." 8 Coke's Reports 107, 118, 77 Eng. Rep. 646, 652 (1610).

5. Cappellettr 42.

6. Although Cappelletti does not define "positivization," his use of the term secmis to imply not only the written articulation of a principle, but also its enactment by some legally competent authority. The distinction between "rigid" and "flexible" con. stitutions is between constitutions which are not subject to change or revision through the ordinary laws (but are changeable, if at all, only by a special amending procedurc) and those which can be changed through ordinary legislative processes. Id. at 25.26 .

7. 5 U.S. (1 Cranch) 137 (1803).

8. Cappelletti 41.

9. Id. at $42-43$. 
Professor Cappelletti argues that systems of judicial review may be classified as either "decentralized" or "centralized." The decentralized system, whose archetype is the United States, gives the power to determine constitutional issues to the entire judiciary. The centralized system, whose archetype is the system established by the Austrian Constitution of 1920, restricts exercise of this power to a special constitutional court. The first is associated primarily with common law countries, the second with civil law nations. Cappelletti places the United States, Australia, Canada, Denmark, Japan, and Norway in the decentralized camp. He includes Austria, Cyprus, Germany, Italy, and Turkey in the centralized camp. A few countries, such as Mexico, Switzerland, Ireland and India, fall somewhere between the two. ${ }^{30}$

The difference between the two systems goes beyond which judicial organs, special or ordinary, perform the function of judicial review. The effect of a judicial determination of unconstitutionality, according to Cappelletti, is very different in centralized and decentralized systems. ${ }^{11}$ In a centralized system, such a decision has an erga omnes effect, invalidating the law for everyone, just as if it had been abrogated by the legislature. The effect in a decentralized system is more complex. Strictly speaking, a decision in a decentralized system generally has binding effect only upon the parties in the specific case, or inter partes.12 However, since such systems are usually found in common law nations, the doctrine of stare decisis may widen the practical effect of judicial review. ${ }^{13}$

10. Swiss judges, whether cantonal or federal, have a general power and duty to disregard cantonal laws which violate the Federal Constitution, but they have no power to determine the constitutionality of federal laws. There also exists in Switzerland a direct action to challenge the constitutionality of cantonal Iegislation (staatsrcelilliche Beschwerde or recours de droit public) which will lic only before the Federal Tribunal. 1. Roussy, Le Controle Judiciaire DE La Constitutionvalite Des Lots Federales Aux ETats-Unis Et EN SuISSE 126, 128-47 (1969). The power of judicial review in Mexico is confined to the federal judiciary, which has authority to suspend the effects of an un. constitutional statute in a particular case via the remedy of amparo. The state judges have no power to issue writs of amparo. Cossrrrución Polínca arts. 103, 107 (Mexico 1917). In Ireland the power of judicial review is restricted to two courts: the High Court and the Supreme Court; the lower courts have no such poirer. J.M. Keur, FundaMeNTAL Rights in the Irish LAw aNd CoNstrtution 15, 16, 20 (2d ed. 1967). Indian lower courts may decide constitutional questions only if there has been a prior interpretation by their High Courts or the Supreme Court of India. If no such prior interpretation exists, the inferior courts must submit the constitutional question to the High Court. Geck, supra note 1 , at 256 .

11. Cappelletti 85.

12. Id. at 86 .

13. To some extent, this latter effect will depend on whether a law is held to be unconstitutional as applied or on its face; in the latter casc, the law is normally inap: plicable to anyone. Kauper, Judicial Reviero of Constitutional Issues in the United States, in 36 Max-Planck-INstitut Für Austandisches ÖfFentlicies Recitr Und VöthienRECHT, supra note 1 , at 568,611 . 
The two systems also have developed different techniques for raising constitutional questions. In the decentralized system, constitutional issues are presented by private parties in connection with actual litigation, a type of review which Professor Cappelletti labels incidenter.14 The centralized system, as it first developed in Austria in 1920, totally divorced judicial review from normal litigation. Under this type of review, which Cappelletti labels principaliter, constitutional issues could be raised only by the federal executive or state governments in abstract ad hoc proceedings brought directly before the Constitutional Court. ${ }^{15}$

Professor Cappelletti argues that three aspects of the civil law tradition account for its development of a distinct pattern of judicial review. First, civil law countries have adhered to a more rigid doctrine of separation of powers, in which judicial reyiew is regarded as a political function for which the ordinary courts are unsuited. Second, civil law nations have not developed a doctrine of stare decisis and therefore have no doctrinal assurance against conflicting opinions. Finally, the traditional civil law judiciary is less suited to judicial review as it consists of career judges unaccustomed to policy-making decisions. For these reasons, according to Cappelletti, decentralized review in civil law countries has generally failed. ${ }^{16}$

Although Professor Cappelletti uses this framework skillfully to discuss a variety of legal institutions and techniques, the theory contains some fundamental ambiguities. Cappelletti, for example, never defines "natural law" or "higher law"-terms used interchangeably, and somewhat confusingly, throughout the work. Nor does he justify his contention that constitutionalism is merely the "positivization" of common law. Not even "judicial review" is clearly defined, and Cappelletti's use of the term seems to exclude some of the important techniques and practices which courts apply in constitutional interpretation. ${ }^{17}$ These terms have developed complex connotations over

14. Cappelletir 73-74.

15. Id. at $69 \cdot 71,75$.

16. Id. at $59,63-64$.

17. The author seems to restrict his use of the term "judicial review" to judicial determinations of the constitutionality of legislation on its face. It is not clear whether this concept would encompass a decision like Yick Wo v. Hopkins, 118 U.S. 356 (1866), where the Supreme Court held that a statute was unconstitutional as applied, or a decision like Lynch v. Overholser, 369 U.S. 705 (1962), where the Court in cffect re. wrote a federal statute to avoid constitutional doubts. Nor is it clear whether judicial 
the years, and Cappelletti might have dealt with them more precisely and clearly. He also might have explained how the historical development of judicial review in common law countries differed from that in civil law nations. ${ }^{18}$ Moreover, his entire set of classifications seems to exaggerate the differences between the two systems. Indeed, the principaliter pattern of judicial review in its pure form (as described by Professor Cappelletti) existed in only one country, Austria, from 1920 to $1929 .{ }^{19}$ Weren't the two systems more like each otherfrom the beginnings of judicial review-than Cappelletti's analysis would indicate?

But perhaps the major defect of Cappelletti's analysis is his failure to look beyond the form and outward appearances of institutions to their actual power and functioning. Abstract discussion of institutional arrangements without consideration of the political and social contexts in which they operate cannot justify conclusions about the actual effectiveness of judicial review in particular societies. Nowhere does Cappelletti discuss the distinctive cultural or political forces of the national systems which he analyzes. He cites, for example, Weimar Germany and post-World War II Italy and Japan as failures in judicial review. But these failures can hardly be attributed solely to the use of civil law and the conditions associated therewith. All three nations were undergoing postwar dislocations, and all three were experimenting with essentially novel internal orders established largely by victorious nations. Cappelletti also cites the relative insignificance of judicial review in certain Scandinavian civil law countries-Norway, Denmark and Sweden..$^{20}$ But again, Scandinavian nations have other

review would encompass Mapp v. Ohio, 367 U.S. 643, relt. denied, 368 U.S. 871 (1961). where the Supreme Court held that exclusionary rule against admission of illegally' obtained evidence applicable to the states; or Youngstown Sheet and Tube Co. v. Sawyer, 343 U.S. 579 (1952), where the Court decided that the President had exceded his constitutional authority by assuming managerial powers over the steel industr:

18. In Europe, for example, the Austrian constitution of 1920 , written principally by Hans Kelsen, was the first civil Iaw provision (outside the separate and rather special development of the Swiss richterliches Prüfungsrecht) to establish a system of judicial review. What was the background for this novel development in Austria and other countries? Cappelletti might have discussed antecedents of judicial review in jurisprudential theories and in Austrian court practices. He provides a full discussion of Marbury, but virtually ignores the historical antecedents of judicial review in civil law countries, except for a catalogue of technical devices and developments in the Austrian system after 1920. See Cappel.lerti $\mathbf{5 3 \cdot 6 3 .}$

19. A constitutional amendment was adopted in Austria in 1929 providing for review of constitutional issues upon application from the highest ordinany and administrative court whenever a pending case involved a statute of doubtful constitutionality. Germany and Italy have expanded this incidenter aspect of the Austrian system to permit all ordinary courts to stay cases involving constitutional issues and seck their resolution from the constitutional courts.

20. Cappellett 59 . 
characteristics that undercut Cappelletti's conclusions: First, they are remarkable for their political and social stability; second, they have effective non-judicial institutions to resolve social disputes. ${ }^{21}$

Cappelletti also fails to analyze the practical problem of vindicating constitutional rights under various systems and procedures. There is only a rather abbreviated treatment of three specialized procedures -habeas corpus, ${ }^{22}$ amparo, ${ }^{23}$ and Verfassungsbeschwerde ${ }^{24}-$ by which citizens may challenge abridgements of constitutional rights. There is no assessment of either their effectiveness in obtaining rapid judicial determination or the efficacy of judicial remedies in correcting particular injuries and discouraging arbitrary government action. Dealing with such issues requires an inquiry into the actual use of the procedures.

A particularly important political factor which Cappelletti fails to consider is the existence of semi-autonomous governmental subdivisions within a federal system. Arguably, one reason for judicial review under such a federalist system is to insure that the actions of state or regional legislatures conform to the federal constitution. ${ }^{25}$ Unchecked unconstitutional action by state or regional governments may pose a real threat to the very existence of the federal state. The American and Swiss experiences both bear out Justice Holmes' oft-quoted observation:

I do not think the United States would come to an end if we lost our power to declare an Act of Congress void. I do think the Union would be imperiled if we could not make that declaration as to the laws of the several States. ${ }^{28}$

21. The most important nonjudicial institution operating in Scandinavian countries is the ombudsman. For a general discussion of the operation of Scandinavian ombudsmen see W. Gellhorn, Ombudsmen and Others: Citizens' Protectors in Nine Counthies (1966). Gellhorn discusses the systems of Denmark, id. at 1.47; Finland, id. at 48.90; Norway, id. at 154-93; Sweden, id. at 194-255. In these countries, the ombulsman call intervene to protect citizens' interests in cases of abuse of discretion by courts, as wcll as by administrative agencies. $1 d$. at $12,59,164,216,237.39$. In Sweden, where the ombudsman's powers over the courts seem broadest, review sometimes may cover the merits of the judgment, as well as the judge's decisions of procedure. Id. at 298.

22. Cappelletti 19-20.

23. Id. at 20-22.

24. Id. at 22-23.

25. Professor Freund strongly suggests that this is so. Freund, Review and Fad. eralism, in Supreme Court ANd Supreme LAw 86, 87-89 (E. Cahn ed. 1954).

26. Holmes, Law and the Court in The Mind ANd Fairil of Justice Holmes 987 , 390 (M. Lerner ed. 1943). For a comparative discussion of some of the special probleus of federalism and judicial review see $W$. WAgner, THe Federud States and Tulu JUDICIARY 73-130 (1959). 
Cappelletti's categories and theories-despite their general analytical value-fail to fit the experience of judicial review in many Latin American nations. Indeed, except for a brief discussion of the Mexican amparo, he ignores Latin America entirely. In most of these countries an American model of judicial review has been grafted on to a civil law base; they are thus civil law systems with decentralized review. Cappelletti argues that such systems in general will be short-lived and inconsequential. But the experience of certain Latin American nations would seem to suggest the contrary. ${ }^{27}$ Judicial review has existed in some of them for nearly a century and has played a significant role in protecting individual rights.

Judicial review in most Latin American countries could be classified as decentralized; only one has a system that could be classified as purely centralized. ${ }^{28}$ Eight, however, have systems that are neither truly centralized nor decentralized under Cappelletti's analysis. Seven are hybrids, restricting the power of judicial review to the highest regular court instead of entrusting it to a special constitutional court..3 Mexico represents a different kind of hybrid, restricting the power of judicial review to the federal judiciary.30

Similarly, in terms of techniques of presenting constitutional questions, many Latin American countries defy Cappelletti's categories. Colombia, for example, has a decentralized system coupled with a review procedure known, as an accion popular which permits any citizen, irrespective of a personal stake or exhaustion of administrative remedies, to challenge the constitutionality of any law by filing with the Colombian Supreme Court a simple written statement of the

27. See genetally J. GRANT, El Control Jurisdiccional de la Constmucionalid.id DE LAs Leyes (1963); Camargo, The Right to Judicial Protection: "Amparo" and Other Latin American Remedies for the Protection of Human Rights, 3 LAlvien of TIE AuEs. ICAS 191, $195-97$ (1971); Elder, Judicial Review in Latin America, 21 Omo Sr. L.J. 570 (1960).

28. The Court of Constitutionality in Guatemala consists of twelve judges; five are drawn from the Supreme Court and seven from two lower courts. Thus, despite a centralized system, the ordinary judiciary actually decides constitutional questions while wearing different hats. Actions to annul a statute may be brought by the Council of State, the Bar Association, the Public Ministry, or a person aggrieved by the statute (provided he is represented by at least ten practicing lawyers). Cosstrutcios arts. 262.65 (Guatemala 1965).

29. Constrtución Política art. 86 (1925, amended 1943, 1957, 1959, 1967) (Chilc); Constrtución Polírica art. 10 (1949, amended 1963) (Costa Rica); Cosstrrtciós Política art. 96 (El Salvador 1962); Constirución PolíncA arts. 234 \& 235 (Honduras 1965): Constrtución Política art. 167 (1916 Panama 1910); Constitución política arts. 239, 256 (Uruguay 1967); CoNstrtución Polírica art. 215(3) (Venezucla 1961).

30. Constrtuciōn Polímca arts. 103, 107 (Mexico 1917). 
asserted conflict between the law and the constitution. ${ }^{31}$ If the statute is declared unconstitutional, the decision has an erga omnes effect. The law is not technically annulled, but it cannot be enforced there. after. ${ }^{32}$ The Colombian system thus has characteristics of both the centralized and decentralized forms.

Several Latin American nations have another form of judicial con. trol under which a bill passed over a presidential veto based on con. stitutional grounds is sent directly to the nation's Supreme Court for an opinion. ${ }^{33}$ The Supreme Court, performing a role similar to that of the French non-judicial Conseil Constitutionnel, must approve the bill as constitutional before it may be promulgated as law. This anticipatory function in a decentralized system seems inconsistent with Cap. pelletti's analysis.

A decision of unconstitutionality in a decentralized system, according to Cappelletti, operates only inter partes. ${ }^{34}$ In Latin America, however, a wider range of legal effects is frequently associated with such a decision. In Argentina, for example, a declaration of unconstitutionality by the Supreme Court of Justice technically binds only the parties to the case, ${ }^{35}$ but as in the United States, the operation of stare decisis (albeit slightly diluted) tends to give the court's decision an erga omnes effect. ${ }^{36}$ In Mexican amparo litigation five consecutive decisions of the Mexican Supreme Court will establish a case law rule (jurisprudencia), which is binding upon the entire Mexican judiciary. ${ }^{37}$ In Brazil a declaration of unconstitutionality also operates

31. Cosstitución Politica art. 214(2) (1886, amended 1969) (Colombia). Sé generally Grant, Judicial Control of the Constitutionality of Statutes and Administrativic Legis. lation in Colombia: Nature and Evolution of the Present System, 23 So. CAL1F. L. REV. $484,496-504$ (1950).

32. L. Sachica, Constitucionalismo Colombiano 124-30 (2d ed. 1966).

33. Constitución Polírica art. 90 (1886, amended 1969) (Colombia); Consiltuctón Política art. 151 (Ecuador 1967); Consritución Polítics art. 53 (El Salvador 1962); Constitución Política art. 243 (Honduras 1965); Constitución Poí́tics art. 229 (18) (1950, amended 1955, 1959, 1962) (Nicaragua); Cossrirución l'olítics art. 181 (19.16, amended 1956) (Panama); Constirución Potírics art. 173 (Venczuela 1961). $\Lambda$ silullix procedure is employed in Costa Rica, but a two-thirds vote of the Supreme Court is necessary to reject the bill on constitutional grounds. Constirución Polírics art. 128 (1949, amended 1963) (Costa Rica).

34. Cappelletti 86.

35. Anibal Abalos v. Provincia de Mendoza, 255 Fallos 262, 263 [1963.1V] J.A. 22. (1963).

36. S. V. Linares Quintana, 1 Derecho Constrtucional E Instituciones l'oltricas 666-68 (1968); Constrtución Polítics art. 9 ('Provincia de Chaco 1957); Constrtuclón Polínca art. 126 (10)c (Provincia de Santiago del Estero 1939).

37. LEY DE AMparo arts. 192.94 (as amended in 1968) (Mexico). $A$ casc law rule established by the Supreme Court sitting en banc binds the entire judictaryi a rule established by a chamber of the Supreme Court binds that chamber and the lower courts; and a rule established by a Collegiate Circuit Court binds that court and the inferior courts within its territorial jurisdiction. 
inter partes, but since 1934 the Senate has been constitutionally obligated to suspend, either in whole or in part, statutes which have been declared unconstitutional by final decision of the Supreme Federal Tribunal. ${ }^{38}$

The experience of four Latin American countries in particularColombia, Mexico, Argentina, and Brazil-indicates that civil law judges are sometimes capable of carrying out the complex role of judicial review with considerable courage and substantial effect. In these countries, the ordinary judiciary has provided a useful and important check on arbitrary government action. ${ }^{39}$ Indeed, Argentine and Brazilian judges have occasionally utilized their power of judicial review to oppose major executive policies, producing serious clashes. The judiciary has sometimes been purged as a result of these battles with overbearing executives. For example, a Peron-dominated Congress impeached the entire Argentine Supreme Court of Justice in 1946 after it invalidated several statutes and released numerous political prisoners. ${ }^{40}$ Since Brazil's military takeover in 1964, the Supreme Federal Tribunal has sought to preserve constitutional guarantees by invalidating portions of the National Security Law and by releasing political prisoners on writs of habeas corpus. A number of these decisions have aroused the ire of military hard-liners in the government, who have retaliated by packing and unpacking the Tribunal's membership. First, in 1965, they increased the Tribunal's membership

38. Constituiçāo art. 42 (VII) (Brazil, 1969). Constituiçāo art. 64 provides that it is incumbent upon the Federal Senate to suspend the execution, wholly or in part, of any law or decree declared unconstitutional by final decision of the Supreme Federal Tribunal. This measure, which originated in the 1934 Constitution, gives the Senate the task of rendering inoperative, erga omnes, the laws and nomins which the Judiciary refrains from applying, in casu, because of the defect of unconstitutionality.

39. Examination of the en banc constitutional decisions of the Colombian Supreme Court from 1910 through 1962 reveals that the Court invalidated, in whole or in part, the challenged legislation in 100 out of the 225 popular actions which it decided on the merits. See 1 \& 2 N. Pineda, Jurisirudencia Constrtucional De La Conte Suinesie DE Jusricia (1963). According to this study, there were only 329 cases from 1910 to 1962 involving en banc constitutional decisions of the Colombia Supreme Court. Three dealt with permission of the executive to leave the country, and twenty-five concerned legislation vetoed on constitutional grounds. In seventy-six of the remaining popular actions, the Supreme Court avoided the merits.

While there have been many exaggerated claims about the cfficacy of the Mexican amparo, a recent examination of 3700 amparo decisions in which the President of the Republic was a party found that only a little more than 1200 (31 per cent) granted the requested relief. P. Goxzalez Gasanova, Desocracy is Mfexico 21.24 (1970). The value of the underlying data is rather suspect in view of the Mexican practice of naming the President as a purely formal party in some actions (amparo contra leges).

40. See Leonhard, The 1946 Purge of the Argentine Supreme Court of Justice, 4 INTER-Amer. EcoN. AfFairs 73 (1964). In 1957, after Perón's ouster, the Lonardi pro. visional government fired the entire Supreme Court, this time without benefit of the impeachment process. The process was repeated in 1966 after the revolution that brought the military government of General Juan Carlos Ongatia to power. See generally INistrtuto De Ciencia Polmial, la Revolución Argentina (1960). 
from 11 to 16 . Then, as the Tribunal remained defiantly independent, they forced three members into retirement in 1968.11

The Argentine and Brazilian experiences suggest not only that such institutions are exceedingly fragile, but also that they may survive on paper long after they lose all practical effect. They demonstrate, moreover, that the real success of the courts depends on an uncompromising societal commitment to the constitutions they seck to enforce. When a nation lacks such commitment-or is forced to give it up-no court can long exercise effective judicial review. Learned Hand counseled:

[A] society so riven that the spirit of moderation is gone, no court can save; that a society where that spirit flourishes, no court need save; that in a society which evades its responsibility by thrusting upon the courts the nurture of that spirit, that spirit in the end will perish. ${ }^{42}$

Fortunately, many societies are not so riven that they lack internal moderating forces. Judicial review can be a significant part of the checking and balancing process, in addition to nudging socictics (through its educational impact) toward greater respect for fundamental constitutional principles. Hand's warning nonetheless suggests the need for study of the social and economic conditions conducive to judicial review-an empirical inquiry into what makes judicial review succeed and what makes it fail. Professor Cappelletti does not provide such a study; nor does he promise it. But his work will be of immense value in providing a theoretical framework for further thought and research. He has given us a remarkably lucid and incisive picture of the many forms judicial review has taken, and may take.

41. R. Schineider, THe Political System of BraziL 172, 275 (1971).

42. Hand, The Contribution of an Independent Judiciary to Civilizalion, in '1'lle SpIRIt of Liberty 172, 181 (I. Dilliard ed. 1952). 